\title{
STATUS KEBERLANJUTAN DAN STRATEGI PENGELOLAAN EKOSISTEM MANGROVE KABUPATEN MEMPAWAH, PROVINSI KALIMANTAN BARAT
}

\author{
Benny Khairuddin'), Fredinan Yulianda²), Cecep Kusmana ${ }^{3)}$ \& Yonvitner ${ }^{2)}$ \\ 1)Pengelolaan Sumber Daya Pesisir dan Laut, IPB \\ 2)Departemen Manajemen Sumber Daya Perairan, IPB \\ 3)Departemen Silvikultur Fakultas Kehutanan IPB
}

Diterima tanggal: 15 Desember 2015; Diterima setelah perbaikan: 5 Januari 2016; Disetujui terbit tanggal 25 Februari 2016

\begin{abstract}
ABSTRAK
Untuk mengelola ekosistem mangrove di Kabupaten Mempawah diperlukan suatu strategi pengelolaan ekosistem mangrove secara terpadu dan berkelanjutan, untuk itu dilakukan evaluasi status keberlanjutan melalui 21 indikator yang dikelompokkan kedalam empat dimensi yaitu ekologi, ekonomi, sosial, hukum dan kelembagaan. Indikator-indikator tersebut diperoleh dari penelitian terdahulu, studi pustaka, CIFOR dan LEI menyangkut Sustainable Forest Management (SFM), serta berdasarkan pengamatan di lapangan. Hasil modifikasi indikator tersebut dinamai Rap-MEcosytem pada skala (0-100) memperlihatkan status keberlanjutan pengelolaan ekosistem mangrove multidimensi. Pengelolaan ekosistem mangrove dinyatakan cukup berkelanjutan dengan indeks 52,83, begitu halnya dimensi ekonomi 59,66, sosial 59,27 dan hukum/ kelembagaan 52,33 sedangkan dimensi ekologi memiliki status kurang berkelanjutan 44,75 sehingga perlu mendapat prioritas perbaikan. Hasil evaluasi dilanjutkan dengan Analytic Hierarchy Process (AHP) sehingga didapatkan strategi pengelolaan dengan prioritas : (a) melengkapi legalitas pengelolaan wilayah pesisir dengan menyusun Rencana zonasi Pengelolaan Wilayah Pesisir dan Pulau-Pulau Kecil (RZWP-3K) dan turunannya, (b) meningkatkan personil, kapasitas, kualitas, sarana dan prasarana petugas penyuluh perikanan dan kelautan yang hanya berjumlah 5 orang serta penyuluh kehutanan yang berjumlah 6 orang, (c) melakukan reboisasi dan rehabilitasi ekosistem mangrove terutama di Kecamatan Sungai Pinyuh yang paling banyak mengalami degradasi.
\end{abstract}

Kata kunci: Mangrove, SFM, Rap-MEcosytem

ABSTRACT

To manage the mangrove ecosystem in Mempawah Regency it well needs a strategy mangrove ecosystem management in an integrated and sustainable. This is done by evaluating the status of sustainability through 21 indicators grouped into four dimensions, ie the ecological, economic, social, legal and institutional. The indicators are obtained from previous studies, literature, CIFOR and LEI concerning Sustainable Forest Management ( SFM), and based on observations in the field. Results of the indicator modification called Rap - MEcosytem on s kala (0-100) show the status of sustainable management of mangrove ecosystems stated quite sustainable multidimensional index as well as the economic dimension 52.83, 59.66, 59.27 social and legal/institutional 52.33 whereas the ecological dimension has less sustainable status 44.75 so it should be a priority repair. Results of these evaluations proceed with the Analytic Hierarchy Process (AHP) to obtain a management strategy with priorities: (a) complete the legality of the management of coastal areas by arranging RZWP-3K and derivatives, (b) increase the personnel, capacity, quality, facilities and infrastructure extension workers fisheries and marine which amounted to only 5 people as well as forestry extension numbering 6, and (c) reforestation and rehabilitation of mangrove ecosystems, especially in Sungai Pinyuh most degraded.

Keywords: Mangrove, SFM, Rap-MEcosytem

\section{PENDAHULUAN}

Ekosistem mangrove merupakan sumber daya alam tropika dan sub tropika yang mempunyai manfaat dengan pengaruh yang sangat luas. Besarnya peranan ekosistem mangrove bagi kehidupan dapat diketahui dari banyaknya jenis binatang dan tumbuhan yang hidupnya tergantung pada ekosistem mangrove.

Saat ini ekosistem mangrove semakin terdesak oleh kecenderungan makin meningkatnya kebutuhan untuk menggunakan lahan untuk memenuhi kebutuhan manusia, sehingga mengancam kelestariannya.

Ekosistem mangrove di Kabupaten Mempawah dalam kurun waktu 25 tahun terakhir mengalami degradasiseluas $250,11 \mathrm{Ha}$, luas mangroveyang tersisa hanya 739,31 Ha ditahun 2014 (Khairuddin etal., 2015).

Banyak upaya yang dilakukan selama ini baik dilakukan pemerintah maupun masyarakat dalam mengelola ekosistem mangrove belum menunjukkan hasil yang baik. Evaluasi menyeluruh diperlukan melalui analisis secara komprehensif di semua sektor baik ekologi, ekonomi, sosial, hukum/kelembagaan sebagai umpan balik didalam menyusun strategi kebijakan pengelolaan ekosistem mangrove secara terpadu dan berkelanjutan. Merumuskan strategi kebijakan pengelolaan ekosistem mangrove dimulai dari melakukan identifikasi terhadap atribut-atribut penting dan mengelompokkannya kedalam masingmasing dimensi, dilakukan evaluasi menggunakan model Multi Dimensional Scalling (MDS), menyusun penerapan strategi kebijakan melalui pendekatan 
taktis, efisien dan efektif didalam penentuan kebijakan prioritas melalui pendekatan AHP (Chen et al., 2008) dirumuskan melalui pertimbangan terhadap atribut yang paling berpengaruh untuk penentuan strategi kebijakan didasarkan pengalaman, kepakaran, data di lapangan dan studi literatur yang menjadi pertimbangan penilaian.

\section{METODE PENELITIAN}

Status keberlanjutan dianalisis dengan analisa MDS pada empat dimensi keberlanjutan, yaitu dimensi ekologi, ekonomi, sosial, hukum dan kelembagaan. Indikator tersebut diperoleh dari Center for International Forestry Research (CIFOR) dan Lembaga Ekolabeling Indonesia (LEI) menyangkut Sustainable Forest Management (SFM) yang disesuaikan melalui penelitian terdahulu, studi pustaka dan pengamatan lapangan. Modifikasi indikator tersebut dinamai RapMEcosytem indikatornya: (1) dimensi ekologi: jenis fauna penyusun ekosistem mangrove, jenis flora mangrove, kerapatan tajuk mangrove, luasan mangrove per hektar, kualitas perairan, (2) dimensi ekonomi: tingkat kesejahteraan nelayan, aksesibilitas wilayah pengelolaan ekosistem mangrove, inventarisasi pemanfaatan mangrove, anggaran pemerintah untuk mengelola mangrove, (3) dimensi sosial: kesadaran masyarakat terhadap pentingnya menjaga ekosistem mangrove, tingkat pendidikan masyarakat, kerusakan ekosistem mangrove oleh masyarakat, partisipasi masyarakat dalam pengelolaan ekosistem mangrove, (4) dimensi hukum dan kelembagaan: keberadaan lembaga penyuluh perikanan, koordinasi antar pemerintah, provinsi dan daerah (vertikal), koordinasi antar lembaga di pemerintah daerah (horizontal), status kelompok nelayan, pembudidaya dan pemasar ikan, ketersediaan peraturan pengelolaan ekosistem mangrove, legalitas kawasan mangrove, penegakan hukum di ekosistem mangrove. Skala indeks keberlanjutan mempunyai selang 0-100 (Susilo, 2003) yaitu: 0-25 (buruk), 26-50 (kurang), 51-75 (cukup) dan 76-100 (baik). Menguji nilai galat dilakukan analisis Monte Carlo, sebanyak 25 kali ulangan (Kavanagh \& Pitcher 2001). Analisis leverage dilakukan untuk mengetahui atribut yang sensitif setiap dimensi yang menjadi atribut terpilih untuk dianalisis kembali secara multidimensi. Nilai stress mengukur seberapa dekat nilai jarak dua dimensi dengan nilai jarak multidimensi. Nilai stress dilambangkan (S) dan koefisien determinasi (R2) hasil analisis yang baik ditunjukkan stress rendah $S<0,25$ dan nilai R2 tinggi (Fauzi \& Anna 2002).

Tabel 1.

Profil responden indeks keberlanjutan dan kebijakan pengelolaan

\begin{tabular}{llll}
\hline Profesi & Jumlah orang & \multicolumn{2}{l}{ Jenis Kelamin } \\
\cline { 3 - 4 } & & \multicolumn{2}{l}{ Laki-laki Perempuan } \\
\hline Pemerintah & 6 & 5 & 1 \\
Nelayan & 6 & 4 & 2 \\
LSM & 6 & 6 & 2 \\
Tokoh masyarakat & 6 & 3 & 3 \\
Peneliti perguruan tinggi & 6 & 22 & 8 \\
\hline
\end{tabular}

Tabel 1 memperlihatkan sebanyak 30 responden dari unsur pemerintah yaitu: Pemerintah Pusat (BPSPL Pontianak, BKSDA) Pemerintah Provinsi (Dinas Perikanan dan Kelautan), Pemerintah Kabupaten (BAPPEDA, BLH, Dinas Perikanan dan Kelautan), nelayan yang tergabung kedalam Kelompok Usaha Bersama (KUB) Kecamatan Sungai Pinyuh, Mempawah Timur, Mempawah Hilir dan Sungai Kunyit, Lembaga Swadaya Masyarakat (LSM), tokoh masyarakat setempat, peneliti kehutanan di Universitas Tanjungpura dan peneliti perikanan Politeknik Negeri Pontianak. Strategi kebijakan dilakukan melalui pendekatan AHP berdasarkan pertimbangan faktor paling berpengaruh menentukan prioritas didasarkan persepsi responden menentukan bobot dan prioritas hasil penilaian. Prinsip kerja AHP adalah penyederhanaan persoalan kompleks, tidak terstruktur, strategis dan dinamis tertata dalam suatu hirarkhi (Marimin, 2004). Tahapan AHP sebagai berikut: (1) mendefinisikan persoalan dan rincian pemecahan yang diinginkan; (2) membuat struktur hirarkhi diawali tujuan umum, kriteria dan kemungkinan alternatif; (3) membuat matriks perbandingan berpasangan menggambarkan pengaruh setiap elemen terhadap tujuan setingkat di atasnya, berdasarkan judgement stakeholders menilai tingkat kepentingan satu elemen dibandingkan elemen lainnya. Mengkuantifikasi data kualitatif skala Saaty; (4) melakukan perbandingan berpasangan; dan (5) menguji konsistensi Judgement stakeholders jika nilai indeks konsistensi $(>0,1)$ maka 
pengambilan data diulangi atau dikoreksi. Perhitungan indeks konsistensi menyatakan ukuran tentang konsisten pembobotan berpasangan (Saaty, 2013) seperti terlihat dalam tabel 2.

Konsistensi besaran tertentu cukup baik atau tidak diketahui rasio jika dianggap baik apabila nilai Consistency Ratio $(\mathrm{CR})<0,1$, dimana Random Indeks (RI) mengikuti tabel yang Oarkride Laboratory dalam Tabel 3.

Tabel 2.

\section{HASIL DAN PEMBAHASAN}

Status keberlanjutan didasarkan pada ke21 atribut yang disepakati melalui data dan telaah pendapat responden menunjukkan pengelolaan secara multidimensi cukup berkelanjutan dengan indeks 52,83 dimana nilai ini mendekati kategori kurang berkelanjutan $<50$ seperti Gambar 1 .

Hasil pengukuran statistik dalam RapMecosystem terhadap setiap dimensi dan multidimensi

\begin{tabular}{|c|c|c|}
\hline Intensitas Pentingnya & Definisi & Penjelasan \\
\hline 1 & Kedua elemen sama penting & $\begin{array}{l}\text { Sumbang peran dua elemen sama besar } \\
\text { pada sifat tersebut }\end{array}$ \\
\hline 3 & $\begin{array}{l}\text { Elemen satu sedikit lebih penting } \\
\text { daripada yang lainnya }\end{array}$ & $\begin{array}{l}\text { Pengalaman dan pertimbangan } \\
\text { sedikit menyokong satu elemen }\end{array}$ \\
\hline 5 & $\begin{array}{l}\text { Elemen satu sangat penting } \\
\text { dibanding yang lain }\end{array}$ & $\begin{array}{l}\text { Pengalaman dan pertimbangan } \\
\text { dengan kuat mendukung satu } \\
\text { elemen atas yang lain }\end{array}$ \\
\hline 7 & $\begin{array}{l}\text { Elemen satu jenis lebih penting } \\
\text { dari elemen yang lain }\end{array}$ & $\begin{array}{l}\text { Satu elemen dengan kuat } \\
\text { dominannya telah terlihat dalam praktek }\end{array}$ \\
\hline 9 & $\begin{array}{l}\text { Elemen satu mutlak lebih penting } \\
\text { dari elemen yang lain }\end{array}$ & $\begin{array}{l}\text { Bukti menyokong kuat elemen satu } \\
\text { secara tegas lebih dominan }\end{array}$ \\
\hline $2,4,6,8$ & $\begin{array}{l}\text { Nilai-nilai diantara dua } \\
\text { pertimbangan yang berdekatan }\end{array}$ & $\begin{array}{l}\text { Kompromi diperlukan antara dua } \\
\text { Pertimbangan }\end{array}$ \\
\hline Resiprokal & $\begin{array}{l}\text { Jika untuk aktifitas i mendapat satu } \\
\text { angka bila dibandingkan dengan } \\
\text { aktifitas j, maka j mempunyai nilai } \\
\text { kebalikan dari i }\end{array}$ & \\
\hline
\end{tabular}

Tabel 3.

Standarisasi nilai RI

\begin{tabular}{llllllllllllll}
\hline $\mathrm{N}$ & 1 & 2 & 3 & 4 & 5 & 6 & 7 & 8 & 9 & 10 & 11 & 12 & 13 \\
\hline $\mathrm{R} 1$ & 0,00 & 0,00 & 0,58 & 0,90 & 1,12 & 1,24 & 1,32 & 1,41 & 1,45 & 1,49 & 1,51 & 1,48 & 1,56
\end{tabular}

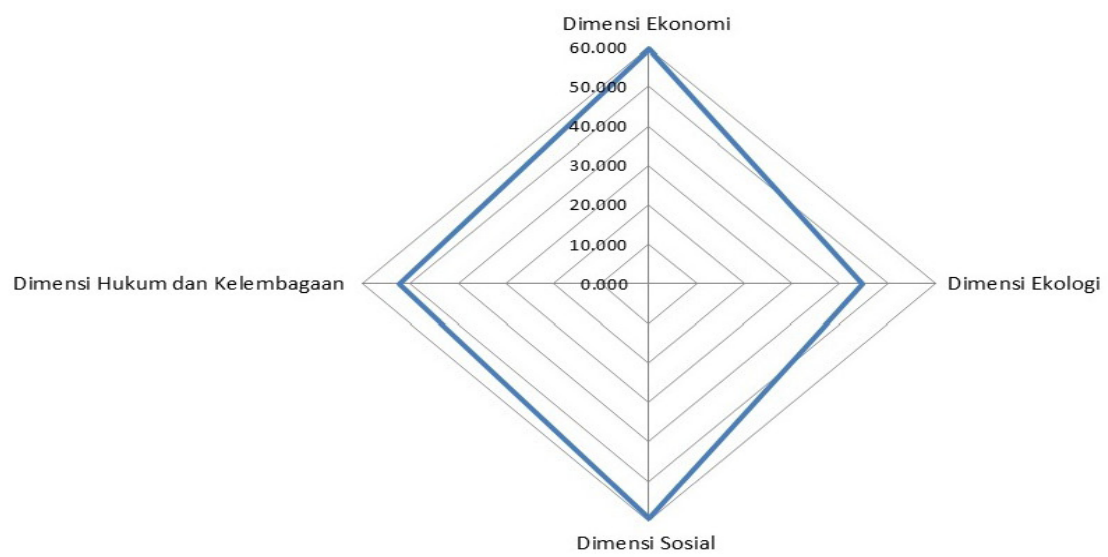

Gambar 1. Diagram layang-layang nilai indeks keberlanjutan per dimensi. 
terlihat dalam Tabel 4 yang menentukan perlu tidaknya penambahan indikator untuk mendekati kondisi sebenarnya.

Setiap dimensi maupun multidimensi memiliki nilai S lebih $<(0,25)$, artinya nilai stress analisis MDS cukup memadai, berbeda dengan nilai koefisien determinasi (R2) baik jika mendekati 1 sehingga $S$ dan R2 menunjukkan seluruh atribut pada analisis keberlanjutan cukup baik menerangkan keempat dimensi. Menguji tingkat kepercayaan setiap dimensi digunakan analisis Monte Carlo (Tabel 5) yang menunjukkan perbedaan kecil artinya analisis MDS memiliki tingkat kepercayaan tinggi dalam mengevaluasi status keberlanjutan. Atribut pengungkit / leverage paling sensitif dipilih sebanyak dua atribut setiap dimensi untuk proses selanjutnya.

Nilai indeks keberlanjutan setiap dimensi dapat dilihat pada Gambar 2 dimana dimensi ekologi menunjukkan status kurang keberlanjutan $(44,75)$ dimana dua diantaranya memiliki nilai paling tinggi sehingga dijadikan pengungkit yaitu: (1) kualitas perairan dan (2) kerapatan tajuk mangrove. Dimensi ekonomi memiliki status berkelanjutan dengan $(59,66)$ dua atribut pengungkit terhadap nilai indeks keberlanjutan dimensi ekonomi, yaitu: (1) tingkat kesejahteraan nelayan dan (2) anggaran pemerintah untuk pegelolaan ekosistem mangrove.

Dimensi sosial terlihat status cukup berkelanjutan $(59,27)$, dua atribut pengungkit terhadap nilai indeks keberlanjutan yaitu: (1) frekuensi pertemuan dengan masyarakat dan (2) kesadaran masyarakat terhadap pentingnya menjaga ekosistem mangrove.
Dimensi hukum/kelembagaan (52,33) artinya cukup berkelanjutan dimana, terdapat dua atribut yang paling tinggi yaitu : (1) legalitas kawasan mangrove, (2) koordinasi antar Pemerintah Pusat, Pemda Provinsi dan Kabupaten.

Atribut pengungkit yang diperoleh dari setiap dimensi dijadikan dasar perumusan strategi kebijakan. Pemerintah, masyarakat, LSM, peneliti yang berperan sebagai pengambil keputusan penting didalam pengelolaan ekosistem mangrove secara terpadu (Patimahu, 2010). Pengujian penilaiannya mempengaruhi strategi kebijakan sebagai aktor yang terlibat dihubungkan kedalam hirarkhi dimensi keberlanjutan untuk menentukan strategi kebijakan pengelolaan ekosistem mangrove secara terpadu dan berkelanjutan melalui analisis AHP. Gambar 3 memperlihatkan bahwa peranan Pemerintah Kabupaten sebagai perwakilan Pemerintah memiliki peranan yang sangat menentukan $(57,0 \%)$, berikutnya $\operatorname{LSM}(18,7 \%)$, masyarakat $(16,8)$, dan peneliti $(7,5 \%)$. Hasil sintesis para aktor menunjukkan dimensi ekologi $(41,1 \%)$ memiliki nilai tertinggi dibandingkan dimensi hukum dan kelembagaan $(26,5)$ dan dimensi sosial $(21,7 \%)$ sedangkan terendah dimensi ekonomi $(10,7 \%)$. Nilai tertinggi memiliki arti bahwa dimensi ekologi harus mendapatkan prioritas utama didalam pengelolaan. Atribut pengungkit yang paling sensitif yang didapatkan dari analisis Rap-MEcosystem selanjutnya dijadikan input factor dalam menentukan strategi kebijakan sebagai berikut:

Kebijakan pengelolaan ekosistem mangrove secara terpadu dan berkelanjutan sangat ditentukan

Tabel 4.

Rap-MEcosystem analisa hasil 4 dimensi keberlanjutan dan multidimensi

\begin{tabular}{lccrc}
\hline Dimensi & Indeks Keberlanjutan & Stress (S) R2 & Iterasi \\
\hline Dimensi Ekologi & 44,75 & 0,176 & 0,930 & 3 \\
Dimensi Ekonomi & 59,66 & 0,187 & 0,925 & 3 \\
Dimensi Sosial & 59,27 & 0,176 & 0,932 & 2 \\
Dimensi Hukum/ kelembagaan & 52,33 & 0,164 & 0,935 & 3 \\
Multi-dimensi & 52,83 & 0,139 & 0,952 & 2 \\
\hline
\end{tabular}

Tabel 5 . Indeks Keberlanjutan Analisis Monte Carlo dengan Analisis Rap-MEcosystem

\begin{tabular}{llll}
\hline Dimensi & Rap-MEcosystem & Monte carlo & Perbedaan \\
\hline Dimensi ekologi & 44,75 & 44,58 & 0,17 \\
Dimensi ekonomi & 59,66 & 59,74 & $-0,08$ \\
Dimensi sosial & 59,27 & 58,72 & 0,55 \\
Dimensi hukum dan kelembagaan & 52,33 & 52,09 & 0,24 \\
\hline
\end{tabular}



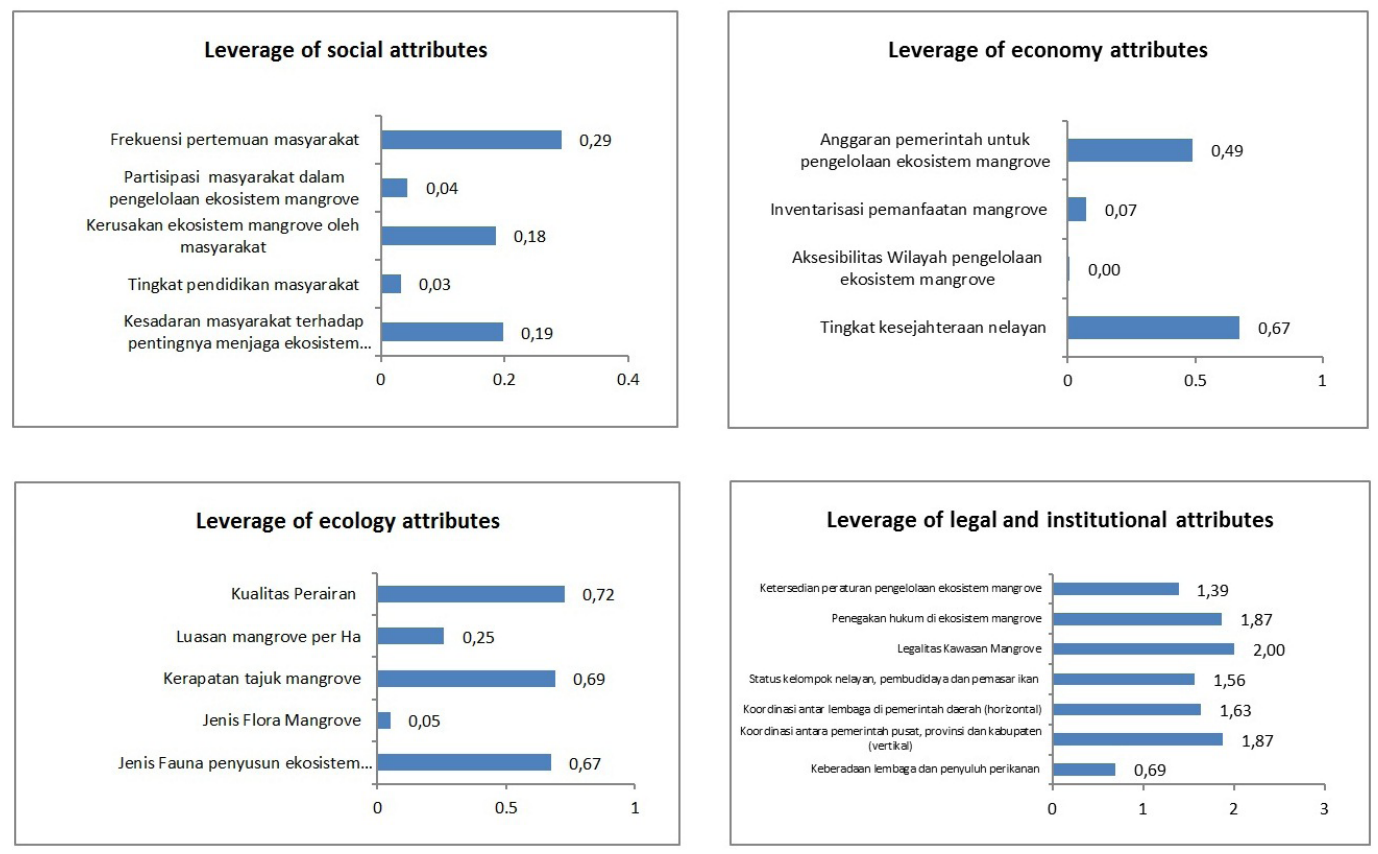

Gambar 2. Hasil Analisis leverage Rap-MEcosystem dimensi ekologi, ekonomi, sosial, hukum/kelembagaan.

Dynamic Sensitivity for nodes below: Goal: Strategi Kebijakan Pengelolaan Ekosistem Mangrove Secara Terpadu dan Berkelanjutan
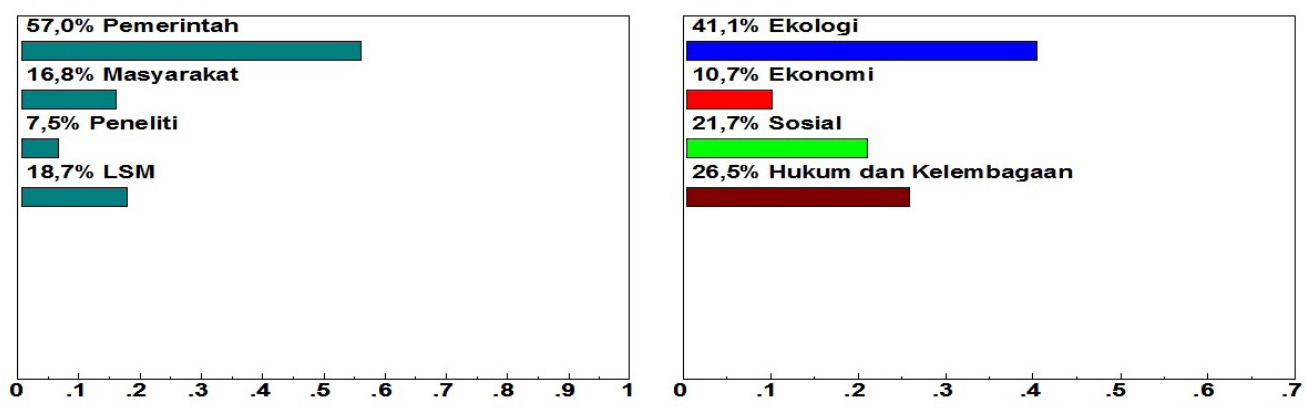

Dynamic Sensitivity for nodes below: Alternatif kebijakan berdasarkan faktor pengukit analisa keberlanjutan
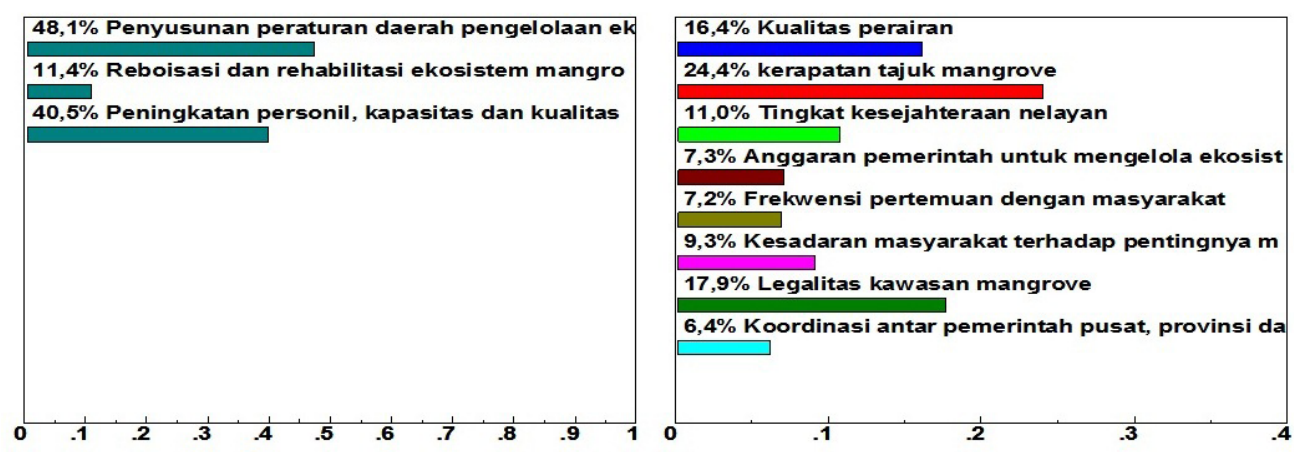

Gambar 3. AHP peran Stakeholders dan alternatif kebijakan berdasarkan leverage status keberlanjutan. 
oleh berbagai atribut pengungkit dalam pengelolaannya. Berdasarkan hasil AHP yang sebagaiman diperlihatkan pada Gambar 4 terlihat bahwa tiga alternatif dalam menyusun kebijakan pengelolaan ekosistem mangrove secara terpadu adalah: (1) menyusun Peraturan Daerah (Perda) pengelolaan ekosistem mangrove $(48,1 \%)$, (2) peningkatan personil, kapasitas petugas penyuluh perikanan dan kehutanan $(40,5 \%)$ dan (3) melakukan reboisasi dan rehabilitasi.

\section{Dimensi Ekologi}

Kualitas perairan perairan merupakan atribut yang paling sensitif. Analisis di Balai Riset dan Standardisasi Industri Pontianak terlihat $\mathrm{pH}$ rata-rata 7,1 terkecuali Kecamatan Sungai Pinyuh yang nilai $\mathrm{pH}$ 5,65 dibawah baku mutu yang ditetapkan. Salinitas menunjukkan rentang 0-32 \%o akibat pengaruh sungai sehingga membentuk zonasi mangrove air tawar hingga payau 0-10 \% dari darat (hulu) masuk hingga garis pantai (hilir), sedangkan pada kecamatan lainnya lainnya membentuk zonasi mangrove air payau hingga asin 10 - 30\% kearah hilir. Salinitas mempengaruhi penyebaran species mangrove (Kusmana, 2003). Oksigen sangat berpengaruh bagi ikan, besarnya oksigen terlarut (DO) di Kecamatan Sungai Pinyuh sebesar 4,74 mg/l, Kecamatan Mempawah Timur 3,87 mg/l dan Kecamatan Mempawah Hilir 4,98 mg/l dikategorikan kurang produktif dimana pada level < $5 \mathrm{mg} / \mathrm{l}$ ikan masih dapat bertahan hidup hanya saja pertumbuhannya menjadi lamban (Bhatnagar \& Devi, 2013). Berbeda halnya kondisi di Kecamatan Sungai
Kunyit dan Pulau Temajo yang memiliki level 5,03 mg/l dan 5,64 $\mathrm{mg} / \mathrm{l}$ dimana perairan ini terkategori produktif. Oksigen terlarut (BOD) adalah jumlah oksigen terlarut yang dibutuhkan oleh organisme yang hidup didalam air untuk menguraikan bahan-bahan pencemar dalam air. Keseluruhan nilai BOD $<20 \mathrm{mg} / \mathrm{l}$ artinya jumlah oksigen yang dibutuhkan untuk proses penguraian sangat baik. Unsur hara yang dianggap paling penting untuk produktifitas perairan adalah nitrogen $(\mathrm{N})$ dan fosfor $(\mathrm{P})$ selain dapat dibentuk melalui proses fotosintesis juga merupakan faktor pembatas pertumbuhan fitoplankton akan tetapi $\mathrm{N}$ dan $\mathrm{P}$ dapat memacu pertumbuhan blooming alga apabila jumlahnya berlebihan. Senyawa nitrogen dalam air laut terdapat dalam bentuk tiga utama yaitu amonia, nitrit dan nitrat yang dipengaruhi oleh kandungan oksigen bebas dalam air (Nugroho, 2006). Pada saat kadar oksigen rendah akan bergerak menuju amonia, terdapat kadar amonia melebihi batas baku mutu di Kecamatan Mempawah Timur 0,626 mg/l dan Kecamatan Mempawah Hilir 0,532 mg/l. Saat oksigen tinggi akan bergerak menuju nitrat sebagai hasil akhir dari proses penguraian nitrogen dalam perairan. Kandungan nitrat di semua Kecamatan melebihi baku mutu $>0,008 \mathrm{mg} / \mathrm{l}$. Tingginya nilai nitrat dapat disebabkan aktifitas manusia seperti limbah domestik dan pertanian yang membawa $\mathrm{N}$ dan $\mathrm{P}$ dalam bentuk garam terlarut dan tersuspensi masuk melalui sungai (James, 2001). Baku mutu timbal air laut baik untuk biota dan wisata bahari berdasarkan Keputusan Menteri Negara Lingkungan Hidup (KMNLH) No 51 Tahun 2004 adalah 0,008 mg/l dan 0,005 mg/l. Nilai timbal di perairan Sungai Pinyuh sebesar 0,239 mg/l

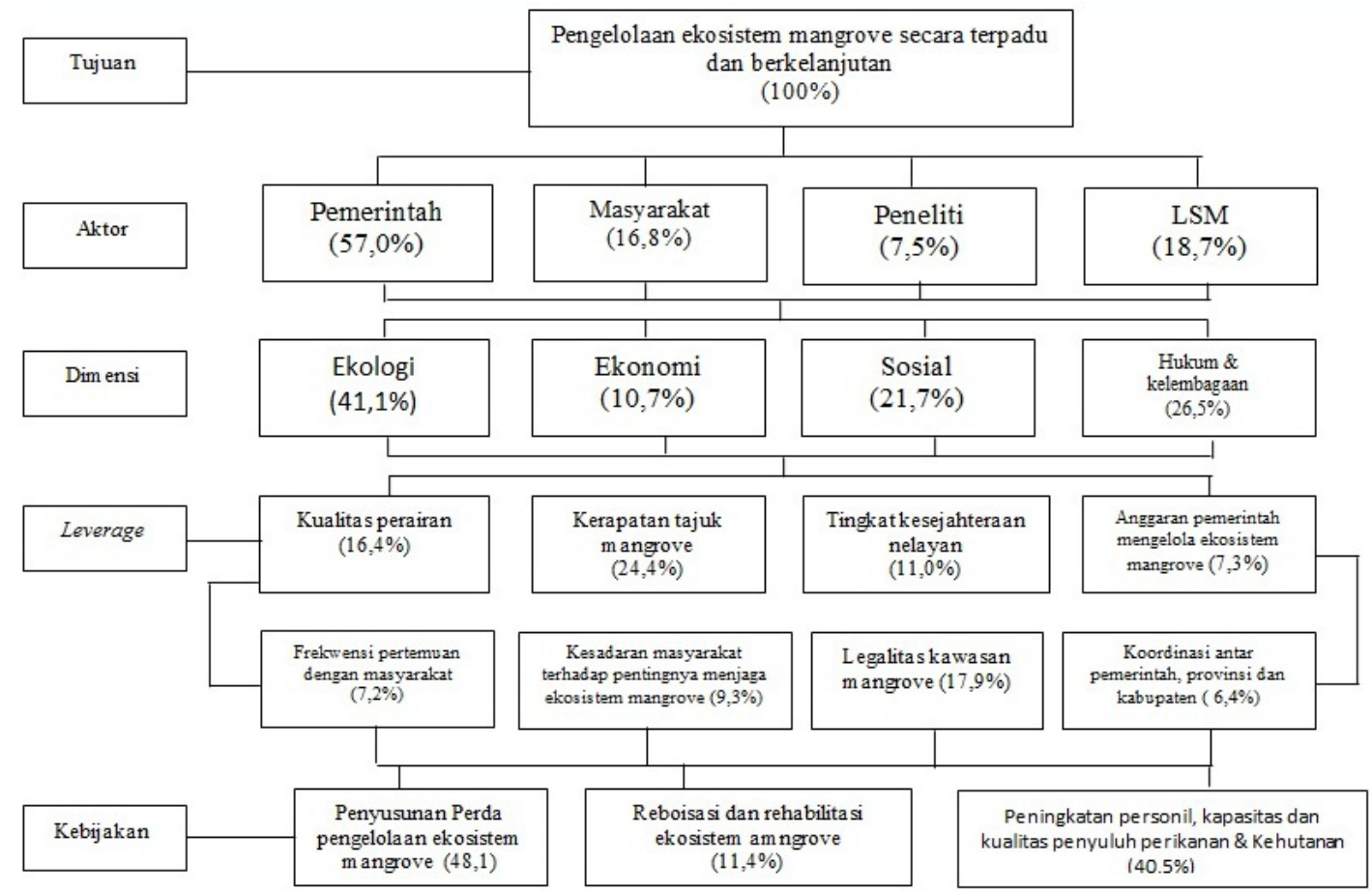

Gambar 4. Hirarki pengelolaan ekosistem mangrove secara terpadu dan berkelanjutan. 
diatas baku mutu untuk biota laut (KMNLH No 51 Tahun 2004 Lampiran III). Total Suspended Solid (TSS) kurang baik terdapat di semua Kecamatan terutama di Pulau Temajo yang mencapai $7.208 \mathrm{mg} / \mathrm{l}$ dikarenakan selain karakteristik jenis tanah di pesisir Kalimantan Barat yang berjenis aluvial juga masukan air tawar yang membawa sedimen dan partikel dari hulu. Total Dissolved Solid (TDS) terdiri dari senyawa organik dan anorganik yang larut dalam air seperti gula dan garam mineral. TDS mencapai $1000 \mathrm{mg} / \mathrm{l}$ terdapat di Kecamatan Mempawah Timur, Mempawah Hilir dan Sungai Pinyuh yang secara umum menggambarkan tingkat salinitas tinggi. Kondisi perairan di wilayah pesisir mulai ditandai indikasi pencemaran kimia yang harus mendapat perhatian dengan jumlah rata-rata Dissolved Oxygen (DO) 4,85 mg/l yang seharusnya $>5 \mathrm{mg} / \mathrm{l}$, amonia 0,32 yang seharusnya $0,3 \mathrm{mg} / \mathrm{l}$ dan Kecamatan Sungai Pinyuh timbal 0,239 mg/l dimana seharusnya $0,008 \mathrm{mg} / \mathrm{l}$.

Selama kurun waktu 25 tahun terakhir telah terjadi pengurangan sebanyak 250,11 Ha luasan mangrove. Penilaian tersebut dijadikan landasan yang dilakukan oleh responden untuk mendalami lebih jauh ekosistem mangrove melalui kondisi lapangan dan dilanjutkan analisis dari data citra landsat 8 tahun 2014 dimana terlihat kerapatan tajuk mangrove secara digital di Kabupaten Mempawah memiliki tingkat kerapatan tinggi $(377,25 \mathrm{Ha})$, sedang $(287,26 \mathrm{Ha})$ dan kerapatan rendah $(74,79 \mathrm{Ha})$. Kerapatan tajuk adalah jumlah individu per hektar yang merupakan salah satu komponen dari struktur vegetasi mulai dari daun, rnting dan pohon. Melalui analisis citra untuk menilai kerapatan mangrove maka akan diketahui kualitas kesehatannya (Satyanaraya, 2011) artinya hampir sebagian atau seluas 48,98 \% mangrove memiliki kualitas dan kuantitasnya berada dalam kategori kurang baik.

\section{Dimensi Ekonomi}

Sebanyak 1.952 atau 94,76\% nelayan Kabupaten Mempawah adalah nelayan kecil (Kabupaten Mempawah Dalam Angka, 2013). Berdasarkan UndangUndang Nomor 31 Tahun 2004 tentang Perikanan yang dimaksud nelayan kecil adalah orang yang mata pencahariannya melakukan penangkapan ikan untuk memenuhi kehidupannya sehari-hari menggunakan kapal perikanan paling besar 5 GT (Gross Ton). Penilaian responden pendapatan dan pengeluaran nelayan dan persepsi terhadap ekosistem mangrove memperlihatkan dari 120 nelayan yang tergabung di Kelompok Usaha Bersama (KUB) $84,17 \%$ pendapatan nelayan rata-rata per bulan diatas Rp1.575.000. Pendapatan nelayan ini menyamai Upah Minimum Kabupaten (UMK) Kabupaten sebesar Rp1.575.000 artinya sebagian besar nelayan dapat memenuhi standar kelayakan hidup minimal. UMK menurut
Kepmenakertrans No. 226/MEN/2000 adalah indikator yang digunakan untuk mengukur biaya kebutuhan minimum yang berlaku di wilayah kabupaten/kota.

Pengelolaan ekosistem mangrove belum menjadi prioritas pengelolaan sumber daya pesisir dan laut, terlihat anggaran yang digunakan sejak tahun 2012 baik dari Pemerintah Pusat, Provinsi maupun Kabupaten hanya untuk reboisasi sedangkan untuk perbaikan atau rehabilitasi pembibitan, pelatihan, monitoring dan penguatan kapasitas untuk pengelolaan belum dialokasikan padahal, jika dilihat dari struktur APBD sektor perikanan dan kelautan menyumbang PDRB terbesar ke tiga sektor pertanian yaitu Rp118,7 miliar dengan konstribusi perikanan laut Rp55,1 miliar atau 6,3 juta ton yang sebagian besar dihasilkan oleh nelayan kecil yang bergantung kepada ekosistem mangrove.

\section{Dimensi Sosial}

Responden menilai masih perlu ditingkatkan kuantitas dan kualitas pertemuan masyarakat dalam acara kegiatan pengelolaan mangrove untuk mensosialisasi dalam memberikan pemahaman akan pentingnya ekosistem mangrove secara terus-menerus. Sosialisasi merupakan mekanisme interaksi dalam masyarakat sesuai dengan peran dan status sosial yang dijalankan masing-masing sehingga diharapkan masyarakat akan mengetahui dan menjalankan hak dan kewajibannya berdasarkan peran status masingmasing dimana menurut (Papalia, 2003) sosialisasi adalah proses mengembangkan kebiasaan, nilainilai, perilaku dan motif untuk dapat menjadi anggota masyarakat.

Masyarakat belum sepenuhnya sadar pentingnya menjaga ekosistem mangrove. Pendapat ini didukung hasil kuisioner penilaian persepsi dari 120 responden hanya sebagian saja atau $58,33 \%$ memahami fungsi mangrove sebagai tempat yang kaya akan keanekaragaman hayati tetapi juga melindungi pantai dari erosi, abrasi dan angin, 53,33\% responden menyatakan perlu dilakukan upaya pelestarian agar ekosistem mangrove terjaga keberadaannya dan sebagian lagi $56,67 \%$ berkomitmen mau menjaga keberadaan ekosistem mangrove dari kerusakan.

\section{Dimensi Hukum/Kelembagaan}

Legalitas kawasan manggrove menjadi atribut yang paling sensitif pada dimensi hukum/kelembagaan dimana ketersediaan peraturan pengelolaan ekosistem mangrove ditingkat lokal hanya ada Perda Nomor 3 Tahun 2014 tentang tata ruang wilayah 2013-2034 yang hanya sampai membahas zona perlindungan pantai. Belum adanya Perda Tata Ruang Pesisir dan PulauPulau Kecil menjadikan legalitas kawasan mangrove 
menjadi tidak jelas sehingga konsistensi terhadap zona perlindungan laut masih banyak diperdebatkan oleh masyarakat setempat. Sengketa tanah timbul akibat pengikatan partikel sedimen dari mangrove-mangrove menjadi permasalahan selanjutnya terbukti, dari hasil kuisioner persepsi masyarakat sebanyak (46,67\%) responden menyatakan tanah timbul tersebut adalah open acces yang artinya dapat dimiliki bagi yang mengusahakannya terlebih lagi apabila tanah timbul tersebut berada dibelakang perkarangan atau kebun hak milik mereka.

Koordinasi secara vertikal antara Pemerintah dan Pemerintah Daerah sering dilakukan tetapi dalam implementasinya dilapangan masih dilakukan terpisah sehingga atribut ini menempati posisi kedua yang harus diperbaiki. Tumpang tindih pengelolaan mangrove ditingkat pusat sering terjadi antara Kementerian Lingkungan Hidup dan Kehutanan (KLHK) dengan Kementerian Kelautan dan Perikanan (KKP). KLHK menilai mangrove dari perspektif kehutanan dan lingkungan hidup sedangkan KKP yang memiliki tugas dan fungsi menyangkut sumber daya pesisir dan laut.

Setelah diketahui leverage masing-masing dimensi selanjutnya, mengetahui peran stakholders, hirarki dimensi menurut stakeholders, hirarki faktor bedasarkan dimensi, dan alternatif kebijakan berdasarkan faktor pendukung sebagai berikut :

1. Peran stakeholders; sebagai aktor, peran pemerintah sebagian besar atau $(57,0 \%)$ sangat berpengaruh dibandingkan peran LSM (18,7\%), masyarakat $(16,8 \%)$ dan peneliti $(7,5 \%)$ dalam pengambilan keputusan.

2. Hirarki dimensi menurut stakeholders; dimensi ekologi $(41,1 \%)$ responden menilai perbaikan yang paling prioritas dilakukan dibanding dimensi sosial $(21,7 \%)$, hukum/kelembagaan $(26,5 \%)$ dan ekonomi $(21,7 \%)$. Hasil yang sama didapat dengan hasil analisis keberlanjutan, dimensi ekologi merupakan dimensi yang paling sensitif.

3. Hirarki faktor berdasarkan dimensi; melalui analisis sebelumnya masing-masing dimensi memiliki prioritas tersendiri, melalui AHP prioritas tersebut di analisis kembali sehingga didapat prioritas utama yaitu: kerapatan tajuk mangrove $(24,4 \%)$ menempati urutan pertama berikutnya, legalitas kawasan mangrove $(17,9 \%)$, kualitas perairan $(16,4 \%)$, tingkat kesejahteraan nelayan $(11,0 \%)$, kesadaran masyarakat terhadap pentingnya menjaga ekosistem mangrove $(9,3 \%)$, anggaran pemerintah mengelola ekosistem mangrove $(7,3 \%)$, frekuensi pertemuan dengan masyarakat $(7,2 \%)$ dan koordinasi antar Pemerintah pusat dan daerah $(6,4 \%)$.
4. Alternatif kebijakan berdasarkan faktor pendukung; penyusunan strategi kebijakan mengelola ekosistem mangrove secara terpadu dan berkelanjutan didasarkan kepada alternatif-alternatif yang dipilih berdasarkan urutan tertinggi sebagai berikut: (1) Perda pengelolaan ekosistem mangrove (48,1\%); Perda Rencana Tata Ruang Wilayah Nomor 3 Tahun 2014 2013-2034 sebagai implementasi UU No 26 Tahun 2006 tentang penataan ruang, belum mengatur wilayah pesisir dan laut. Amanat UU No. 27/2007 jo UU No.1/2014 tentang Pengelolaan Wilayah Pesisir dan Pulau-Pulau Kecil, Pemda diwajibkan menyusun Rencana Zonasi Wilayah Pesisir dan Pulau-Pulau Kecil (RZWP-3-K). Saling melengkapi dan memungkinkan adanya penataan ruang terpadu antara daratan dan laut di wilayah pesisir (Diposaptono, 2013), sehingga berguna bagi Pemda terutama kepastian hukum dan rujukan bagi penanganan konflik pemanfaatan ruang (2) peningkatan personil, kapasitas dan kualitas petugas penyuluh perikanan dan kelautan serta kehutanan $(40,5 \%)$; potensi sektor perikanan yang cukup besar memerlukan penambahan petugas penyuluh perikanan saat ini hanya berjumlah 5 orang dan kehutanan 6 orang. Penyediaan minimal 1 orang di setiap kecamatan dalam upaya memajukan usaha perikanan, aktif menjaga kelestarian ekosistem mangrove yang didukung sarana prasrana (3) reboisasi dan rehabilitasi ekosistem mangrove $(11,4 \%)$; dilakukan secara bersama pada wilayah yang telah hilang atau rusak, mengembalikan minimal 250,11 Ha hilang 25 tahun terakhir. Keterlibatan masyarakat pesisir mulai dari tahap perencanaan, pelaksanaan hingga monitoring menjadi keharusan, masyarakat pesisir lebih mengenal lokasi yang dapat disinkronkan dengan peta hibrida mangrove yang telah dibuat pada penelitian ini.

\section{KESIMPULAN}

Melalui analisis dan pembahasan yang telah dilakukan dapat diperoleh kesimpulan:

1. Status keberlanjutan pengelolaan ekosistem mangrove secara multidimensi dinyatakan cukup berkelanjutan begitu halnya dengan dimensi ekonomi, sosial dan hukum/kelembagaan sedangkan dimensi ekologi memiliki status kurang berkelanjutan.

2. Strategi kebijakan pengelolaan ekosistem mangrove secara terpadu dan berkelanjutan dilakukan dengan prioritas memperkuat legalitas peraturan pengelolaan wilayah pesisir dan laut, meningkatkan personil, kapasitas dan kualitas petugas penyuluh perikanan dan kelautan serta kehutanan dan melakukan upaya reboisasi dan rehabilitasi ekosistem mangrove. 


\section{PERSANTUNAN}

Ucapan terima kasih disampaikan KKP yang telah memberikan tugas belajar dan para responden dari BPSPL Pontianak, BKSDA Kal-Bar, Dinas Perikanan dan Kelautan Kal-Bar, BAPPEDA, BLH, Dinas Perikanan dan Kelautan Kabupaten, nelayan dan tokoh masyarakat Mempawah sehingga penelitian dapat terselesaikan.

\section{DAFTAR PUSTAKA}

M.F. Chen, G.H. Tzeng \& C.G. Ding. (2008). Combining fuzzy AHP with MDS in Identifying the Preference Similarity of Alternatives. Applied Soft Computing. Volume 8. Elsevier.

Khairuddin, B., Yulianda, F., Kusmana, C \& Yonvitner. (2015). Structure of Mangrove Community in Coastal of Mempawah Regency, West Kalimantan Province. Journal of Biology, Agriculture and Healthcare ISSN 2224-3208 (Paper) ISSN 2225093X (Online) Vol.5, No.22, 2015. IISTE.

Bhatnagar A \& Devi P. (2013) Water quality guidelines for the management of pond fish culture. Internasional Journal of Environmental Scieneces Volume 3, No 6, ISSN 0976 - 4402. India.

Diposaptono S. Penyelarasan RZWP-3-K dan RTRW (2013). Buletin Tataruang dan Pertanahan. Direktorat Tataruang dan Pertanahan edisi tahun 2013. Bappenas Jakarta.

James E. C. (2001). Our evolving conceptual model of the coastal eutrophication problem. Marine Ecology Progress Series Vol. 210: 223-253.USA.

Kabupaten Mempawah Dalam Angka Tahun 2014. BPS Kabupaten Mempawah.

Fauzi A. \& S. Anna. (2002). Evaluasi status Keberlanjutan Pembangunan Perikanan: Aplikasi Pendekatan Rapfish (Studi Kasus Perairan Pesisir DKI Jakarta).Jurnal Pesisir dan lautan Vol. 4.3, 43-55.

Kavanagh \& Pitcher. (2001). Rapid Appraisal of Fisheries (RAPFISH) Project. RAPFISH Software Description (for Microsoft Excel). University of British Columbia, Fisheries Centre,Vancouver. No.49pp.

Kusmana, C. (2003). Teknik Rehabilitasi Mangrove. Fakultas Kehutanan IPB. IPB Press. Bogor.

Marimin. (2004). Teknik dan Aplikasi Pengambilan
Keputusan Kriteria Majemuk. PT Grasindo. Jakarta.

Nugroho, A. (2006). Bio Indikator Kualitas Air. Penerbit Universitas Trisakti.

Patimahu, D.B. (2010). Kebijakan Pengelolaan Hutan Mangrove di Kabupaten Seram Bagian Barat, Maluku. Desertasi IPB. Bogor.

Papalia, D. E, Olds, S.W. \& Feldman, R.D. (2003). Human Development. 9th ED McGraw-Hill. New York.

Republik Indonesia. (2004). Keputusan Menteri Negara Lingkungan Hidup No. 51. Jakarta.

Saaty, T.L. (2013). Theory and Applications of the Analytic Network Process, Pittsburgh, RWS Publications.

Satyanaraya, B. (2011). Assessment of Mangrove Vegetation Based on Remote Sensing and Groundtruth Measurements at Tumpat, Kelantan Delta, East Coast of Peninsular Malaysia. Journal of Remote Sensing Vol. 32, No. 6, 20 March 2011, 1635-1650. Taylor \& Francis.

Susilo, S. B. (2003). Keberlanjutan Pembangunan Pulaupulau Kecil : Studi Kasus Kelurahan Pulau Panggang dan Pulau Pari Kepulauan Seribu DKI Jakarta. [Disertasi]. Program Pascasarjana Institut Pertanian Bogor.Bogor.

Undang-Undang Nomor 31 Tahun (2004) tentang Perikanan Jo. Undang-Undang Nomor 45 Tahun 2009 tentang Perikanan.

Undang - Undang Nomor 26 Tahun (2007) tentang Penataan Ruang. 
